\title{
THE GOVERNMENTAL COMMUNICATION OF PRESIDENT DILMA ROUSSEFF: A CONTENT ANALYSIS OF THE PRESIDENCY OF THE REPUBLIC PORTAL
}

\author{
Danusa Santana Andrade \\ danusa.santana.andrade@hotmail.com \\ Universidade Federal de Mato Grosso do Sul. Cidade Universitária. Universitário - CEP: 79070-900. Campo Grande- MS
}

\begin{abstract}
This study presents a content analysis of communication strategies of government of the Presidency of the Republic, a profile outlining the administration of Dilma Rousseff. The research is supported by the concepts of government communication, public opinion, hegemony and agenda-setting. The corpus of this study consists of tools and government communication channels focusing on the presidency website. The study noted that while there is a predominance of political marketing in the past administrations, the administration of President Dilma through the portal, gave greater emphasis to government communication. The research is concluded by briefly discussing the way the presidency to communicate with society, with a different twist on the theme set.
\end{abstract}

KEYWORDS

Government communication; president of the republic; content analysis

\section{INTRODUCTION}

The Brazilian republican regime enabled the implementation of government communication in the presidency which allows, according to Rego (1985: 44), "[...] shelter in democratic systems, all the possibilities of exchange between government and the governed, a constant flow of ideas, bilateral, open and free [...] “. This is the crux of this study aims to highlight a profile of government communication president, Dilma Rousseff, doing a content analysis of the portal of the presidency of the Federative Republic of Brazil. The main objective of this study is to identify the strategies used by the government communication Communication Advisor in the administration of President Dilma Rousseff at the presidential website. The specific objectives are: to determine which channels and government communication tools used by the Office of Communications and investigate how the presidency provides information of public interest in their portal.

The question guiding this research is: how the presidency in the administration of President Dilma Rousseff communicates with society through the portal of the presidency?

The general hypothesis that the unity of this study can be formulated as follows: the strategies of government communication in the administration of President Dilma appear as satisfactory because the used channels and tools are used correctly and allow a closeness with government society accountable for its activities and services and publishing activities of interest to the people. In this sense, the government of President Dilma communication appears as a suitable example of public communication. 
The delimitation of the object of study fell on the portal of the presidency as it is a permanent means of presidential communicate with society and be consistent bibliography on the subject being researched.

The methodology is content analysis because it presents itself as an investigation procedure more appropriate because, as Bardin (1977: 31), "[...] Content analysis is a set of techniques for analysis of communications explains [...] “ The chief executive of Brazil, Dilma Rousseff, the central figure of this research was elected on October 31, 2010 after serving the office of Minister of Mines and Energy of Brazil (2003-2005) and the Chief of the Civil Cabinet of Brazil (2005-2010) during the terms of former President Luiz Inacio Lula da Silva (2003-2011).

The research is important because it aims to contribute to studies of government communication presidential updating the issue that sparked the interest of scientific researchers from the 80 Furthermore, the study presents society with a new perspective on government communications presidency the Republic.

Thus, no claim to be a comprehensive study on the subject, this research proposes a reflection on the implementation of communication strategies for government of the presidency. Considerations resulting from this test can indicate ways and serve as input for researchers, journalists and students wishing to research on the same topic, or simply want to experience a different bias on the proposed topic.

\section{DEVELOPMENT}

\section{GOVERNMENT COMMUNICATION: INSTITUTIONAL ADVERTISING TO ADVERTISING ACTIONS}

The government's communication of the presidency of Brazil has undergone remarkable changes. Rego (1985) argues that the starting point of the current government model was designed in the early 1970s, when the government of Emilio G. Medici (1970-1974) instituted the Special Advisor for Public Relations of the Presidency of the Republic who created campaigns public opinion well prepared and guided by a strong nationalist character.

Brandão (2009: 10) points out that the government's communication in Brazil has historically been of advertising, ie disclosure of their actions and preferably used with serving propaganda in the mainstream media.

Government in the history of communication between the three powers, the executive has always had higher effective presence and visibility in the population. The use of radio during the Getúlio Vargas, passing through various civic campaigns, political campaigns and propaganda from governments, both produced by the military dictatorship as those produced in democratic governments, to marketing with its own set of techniques and methods used in abundance by recent governments, persuasive communication in its various forms of manifestation powerful and unscathed across all political stripes, always being the favorite of the rulers, regardless of ideology or party (Brandão, 2009: 11). 
As Matos (1999), there was shift in government communication during civilian governments. If at first the government of José Sarney (1985-1989) was an attempt to draw a blueprint for participatory public communication, this experience did not survive the Cruzado Plan. After the failure of this are the marketing techniques that will permeate and constitute the core of the government's public communication. Especially from the Fernando Collor de Mello (1990-1992), political marketing techniques have become prevalent.

Matos (1999) argues that during the Itamar Franco (1992-1994) was a certain decline in the use of these marketing techniques, from the government of Fernando Henrique Cardoso (1995-1999) saw the association of government communication to marketing public.

In the period of Luiz Inácio Lula da Silva (2003-2011), one of the most popular presidents in the country in research aimed at Datafolha Institute in September 2010, "[...] for the first time after the military was dealt with the communication government with a concern that he intended to go beyond advertising and political marketing and rescued the notion of civility [...] "as Brandão (2009: 12).

These considerations about the history of the government's communication of the presidency of Brazil indicate that significant changes in this scenario and help to support this research.

\section{GOVERNMENT COMMUNICATION: STRATEGIES OF RELATIONSHIP WITH SOCIETY}

In the following pages, are the concepts of government communication, public opinion, agenda-setting and hegemony that theoretically underlie the study.

Human communication has enabled man to do negotiations with the world, ensuring its survival and socialize, in the society we inhabit. For Rego (1986), the communication which, as a process, symbolically transferring ideas between speakers, are able to, for the simple fact exist, generate influences.

Communication, as Rego supports (1986), is understood as an open system, similar to the company. As a system, the communication is organized by the elements - supply, encoder, channel, message, decoder, receiver, ingredients that vitalize the process.

Within the universe of communication, there is the government communication concept that supports this study and that can be understood, according Brandão (2009) and Public Communication, in that it presents itself as a tool to build the public agenda and directs its work for accountability and short triggers public debate.

Brandão (2009: 5) states that "it is a legitimate form of government accountable and to inform the public projects, actions, activities and policies that place and which are of public interest."

Rego (1985) points out that government communication is a social necessity rather than an infrastructure of support and power for your network, the social segments become aware of what is happening in the various sectors of the Government and, through them, convey the rulers your expectations and desires.

The government's communication is understood by Rego (1985) as the vast formal network established and located within the main governmental organizations to bring the public significance of events occurring at the government objective. 
As wide-area media, involves the activities of journalism, public relations, publicity and advertising, publishing, cinema, radio, television, and actions of informal communication.

The government communication is realized from the daily routine of briefins the Office of the Presidency, passes through institutional programming of films and television movies, network runs on the printed newsletters, newspapers, journals, brochures, flyers, folders, scattered by hundreds of companies and government institutions, projected into the image setting policy for the plans, programs and governmental works and goes to Brasilia headquarters of the Central government, to small rural communities of the country (Rego, 1985: 44-45).

This study is also justified by the concept of public opinion. Lippman (2008: 40) shows that "the outside world those aspects that have to do with the behavior of other human beings, in that the behavior crosses ours, which is dependent on our own, or which is interesting in , we call roughly public opinion. "

Lippman (2008) points out that the images in the heads of these human beings, the image of themselves, of others, are their public opinions. In this sense, the author assumes that what each man does is based not on direct and certain knowledge, but on pictures made by himself or transmitted to it. Thus, the pseudo-environments of these individuals, their internal representations of the world, are a key element of thought, feeling and action.

The media create and present representations of the world of human beings and the internet, in which the object of our study is inserted, also contributes to present facts that can turn into representations of individuals.

Another concept that underlies this theory is the study of hegemony. Gruppi (1978) conceptualizes hegemony and Gramsci argues that hegemony is derived from Greek and means eghestai lead, be a guide, be a leader.

Gruppi (1978) argues that hegemony is the ability to target yourself, conquer alliances, ability to provide a social basis for proletarian state.

When refers to hegemony in Gramsci, Gruppi capacity leader speaks on the direction and domination. In this sense, hegemony is understood not only as political leadership, but also as moral, cultural and ideological direction.

This research is also based on the assumption of agenda-setting, developed by Maxwell E. McCombs and Donald Shaw in the late 1960s during studies of public opinion at election times. For these authors, each receiver would schedule their thoughts and concerns as a result of the action of the media.

The hypothesis holds that the media presents to the public a list of facts about which it is possible to have an opinion and discuss. Wolf (2005) uses Shaw (1979) to state that in consequence of the action of newspapers, television and other media, the public is aware or ignorant, gives attention or neglect, or neglect emphasizes specific elements of public scenarios. People tend to include or exclude themselves in the knowledge that the media includes or excludes the content itself. 
In the context of this study, the application of the concept of agenda-setting features particularly relevant because the object of this research is an electronic means of communication and presents facts and information that individuals may include in their agendas discussions.

\title{
CONTENT ANALYSIS
}

This topic specifically focuses on the analysis of the corpus of this work - the channels and tools used by the Communications Office of the presidency at the gate of the Presidential Palace. We chose to perform content analysis with a quantitative bias to present and describe the corpus of research and applied qualitative analysis is also proposing inferences and interpretations.

Fonseca Júnior (2011) states that content analysis in broad concept, refers to a method of the humanities and social sciences for the investigation of symbolic phenomena through various research techniques. This set of methodological tools, continuous improvement, has been used at least since the eighteenth century when a Swiss court thoroughly analyzed a collection of 90 anonymous hymns, called The songs of Zion, to see if they contained harmful ideas.

To Hercovitz (2007), is a part of humanity disappeared tomorrow, but there remained books, newspapers, magazines, videos, films, CDs and DVDs, files with speeches and letters and related artifacts, we would have the necessary material to interpret the social life of a time. A content analysis of the media would be one of the most efficient methods to track this civilization for its excellent ability to make inferences about what was printed or engraved.

\begin{abstract}
Widely used in various branches of empirical social science content analysis reveals itself as a very useful method for on journalistic research. Can be used to detect trends and models in the analysis of newsworthiness criteria, guidelines and schedules. It also serves to describe and classify products journalistic genres and formats, to evaluate the production characteristics of individuals, groups and organizations, to identify elements typical, representative examples and differences and to compare the journalistic content of different media in different cultures (Hercovitz, 2007: 123).
\end{abstract}

The universe of this content analysis includes channels and communication tools government disclosed on the website of the Presidency. The definition of the universe of research in content analysis, to Bardin (1977), covers the pre-analysis stage of the organization itself. Generally (Bardin, 1977: 95), "this first phase has three missions: the choice of documents to be submitted to analysis, the formulation of hypotheses and objectives and developing indicators to substantiate the final interpretation."

After choosing the content of the analysis, it follows to verify the hypotheses presented earlier in this study that considers relevant figure, as objectives, which channels government and communication tools used by the Office of Communications and 
investigate how the presidency offers information of public interest in their portal. The data obtained in the universe of analysis will serve to substantiate the final interpretation.

After this phase of the pre-analysis, passes to the categorization phase of the group studied. Bardin (1977) explains that the categorization is a sorting operation of the constituent elements of a set. Bardin (1977: 118) refers to "[...] is a categorization process structuralist type and consists of two stages, the inventory (isolating elements) and classification: divide the elements [...]". The category chosen was "space for government communication channels."

\section{CORPUS ANALYSIS}

In the following pages, the research is dedicated to the quantitative content analysis, presenting the government communication channels and tools used in the portal of the Palácio do Planalto.

On the portal page, as shown in Figure 1, show the President, Vice-President, President, Press, Blog do Planalto, Multimedia, Special Legislation and links, which are objects of the present analysis.

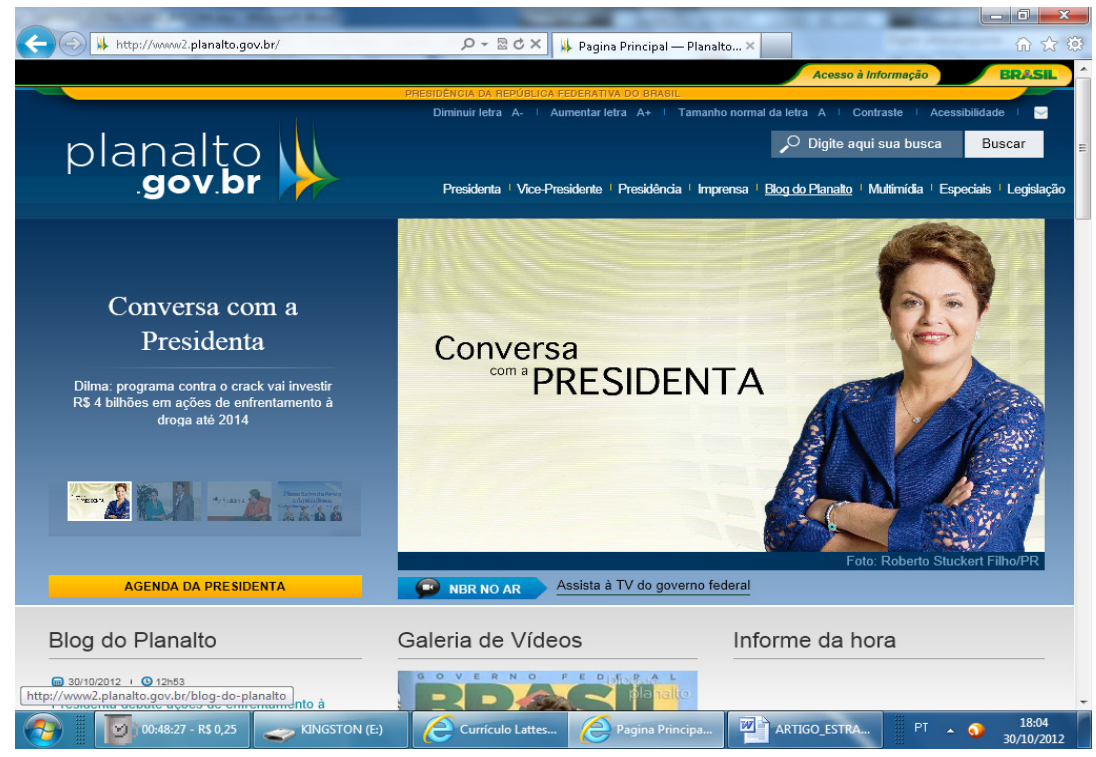

Figure 1- main page of the website of the Presidency of the Republic Source: website of the Presidency of the Republic (2012)

In President (figure 2) link are: Biography, official photo, Responsibilities, Office staff, Contacts and ceremony, President of Agenda Speeches of the President, the President Talk, Talk with the President, Coffee with the President, "Use of the word President "Guidelines and government, plus gallery of videos and photo gallery, Audios Featured, latest News.

The Vice-President (Figure 3) show link: Biography, News, Photos, Audios, Videos, Official residence, Flag Banner, Vice President agenda, the agenda Acting President, Access to Information, and Picture Gallery, Gallery Video, Audio Spotlight.

In the Presidency (Figure 4) link contained links: the Federal Constitution, Ministers, Ministries, Legislation, National Symbols, Flag, Coat of Arms, Seals, Hymns, Flag Banner, 
palaces and official residences, Palácio do Planalto, the presidential palace, Grange Bent Palace Jaburu, Structure of the Presidency, the Presidency Library, Gallery of Presidents.

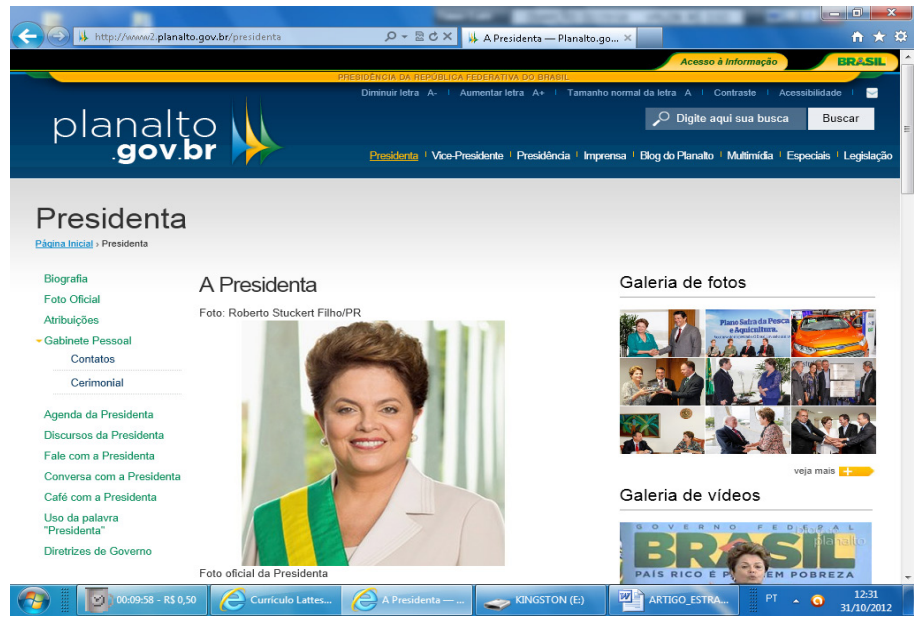

Figure 2 - Link President

Source: website of the Presidency of the Republic (2012)

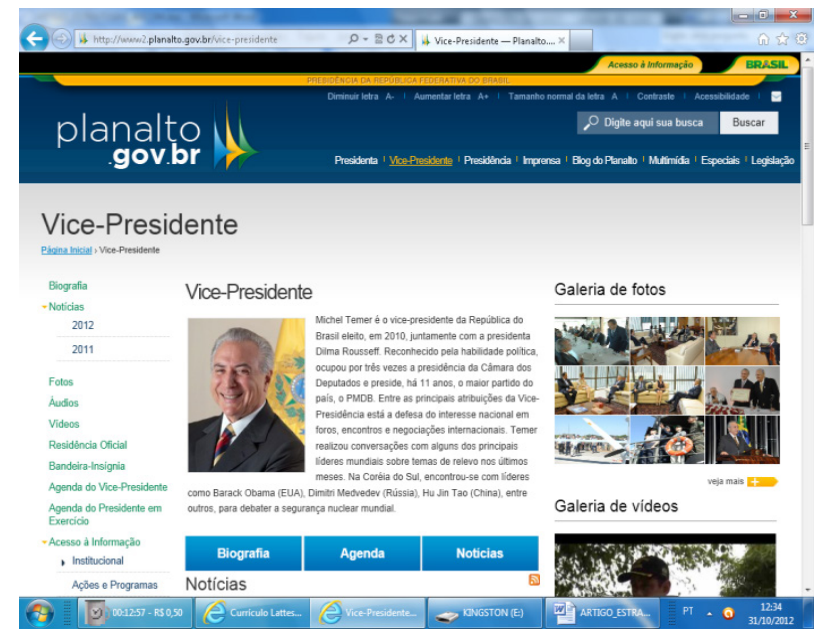

Figure 3 - Link Vice President

Source: portal of the President of the Republic (2012)

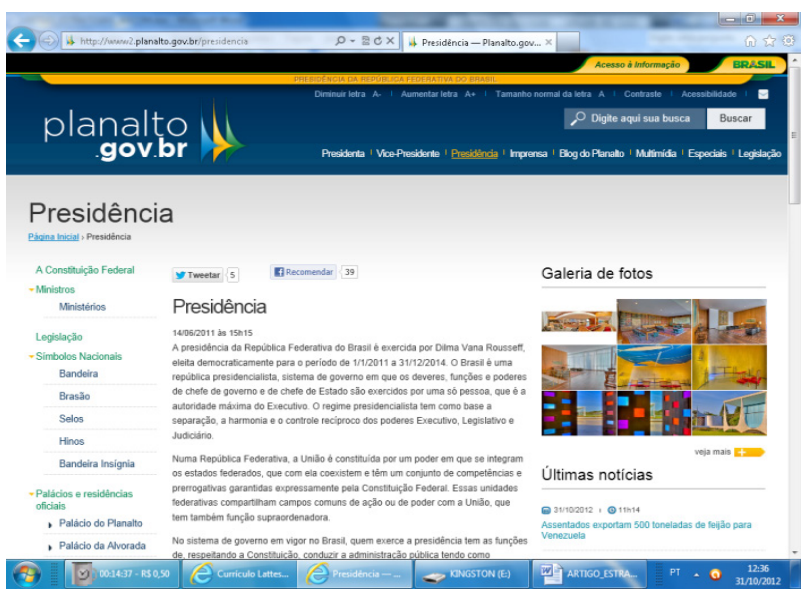

Figure 4 - Link Presidency

Source: website of the Presidency of the Republic (2012) 
In the Press in the News Government (figure 5), there are news link, photos and videos galleries and links: About the Department of Press, Aides Contacts of Press and Communication of the Government, the Secretary of Press Contacts, Agenda President, Vice-President of the agenda, the President in Exercise Diary, Calendar January to July 2011, and Speeches, Interviews, Official Notes, Articles, Briefings, Releases, Government News, Coffee with the President, Conversation with the President, Good Day Minister, Brazil in Tariff, Brazilian, Accreditation and Reports of the Secretary of the Press.

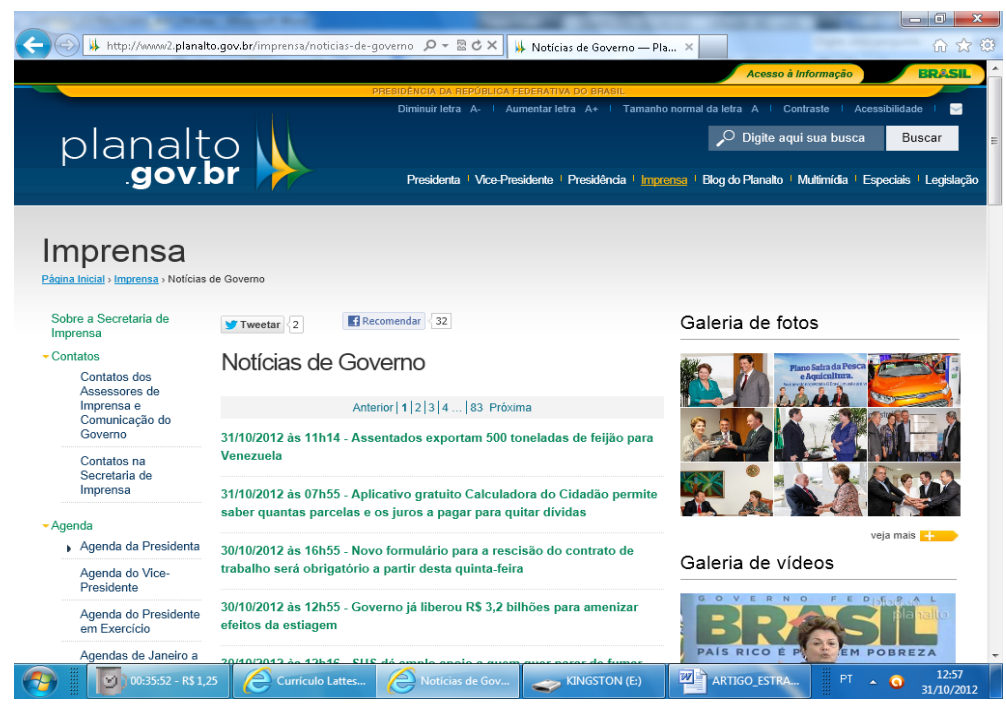

Figure 5- Link Press

Source: website of the Presidency of the Republic (2012)

Coffee link in with the President (figure 6), included in the press item, the links appear radio programs released every seven days. The interviews are typed and is also provided a link to hear the interview in full.

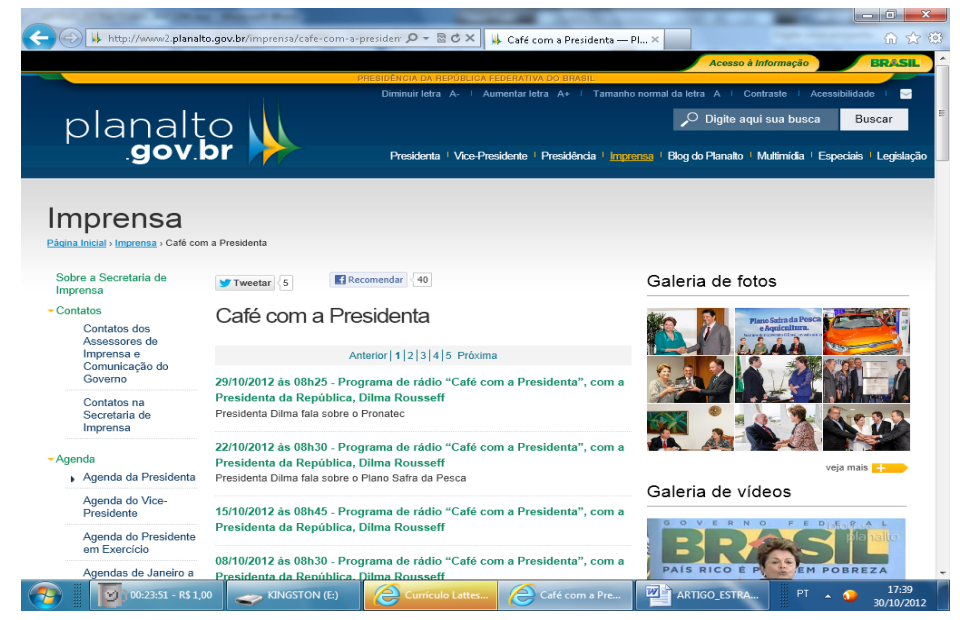

Figure 6 - Link Coffee with the President

Source: website of the Presidency of the Republic (2012) 
In Conversation with the President (figure 7) link, Dilma publishes a weekly column on issues such as: Light for All Program, organ donation, Minha Casa, Minha Vida program on teaching full More Education, answering questions from the population.

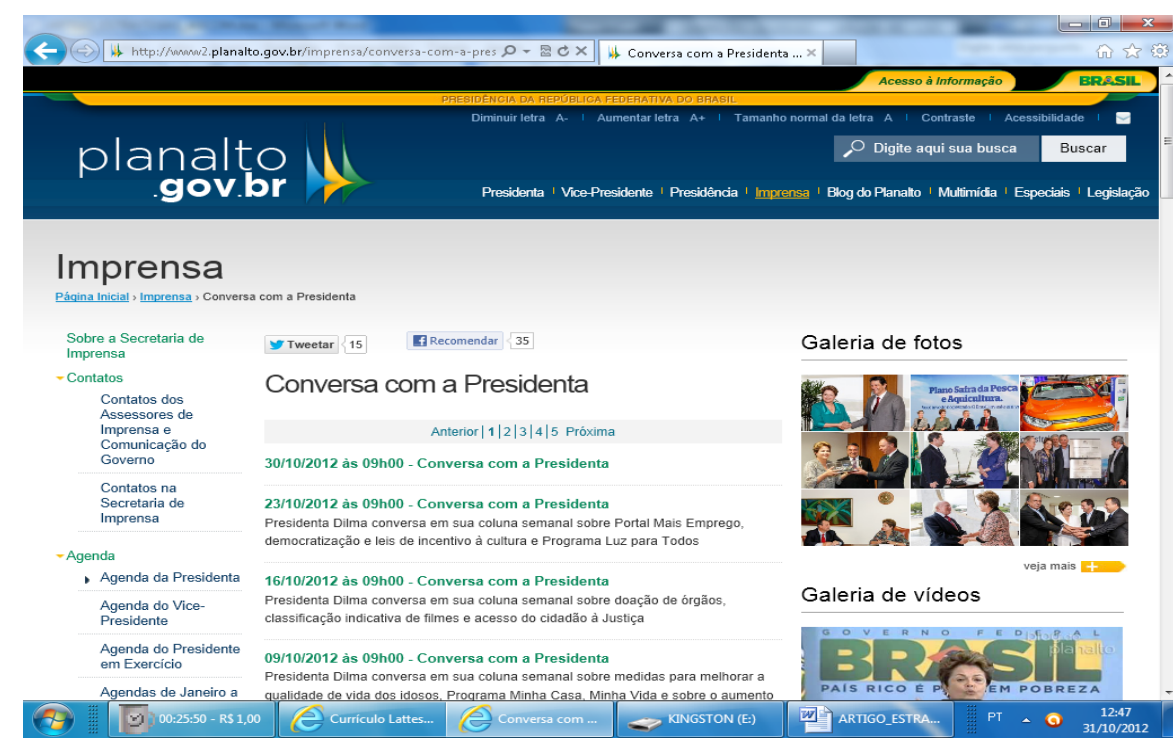

Figure 7 - Link Conversation with the President Source: website of the Presidency of the Republic (2012)

Good morning Minister in the program (Figure 8), the ministers are interviewed on topics such as: Pink October, actions to reduce traffic accidents and joint efforts for health, recovery industry and automotive regime, Plan to Prevent Violence Against the Black Youth, reduced electricity tariff.

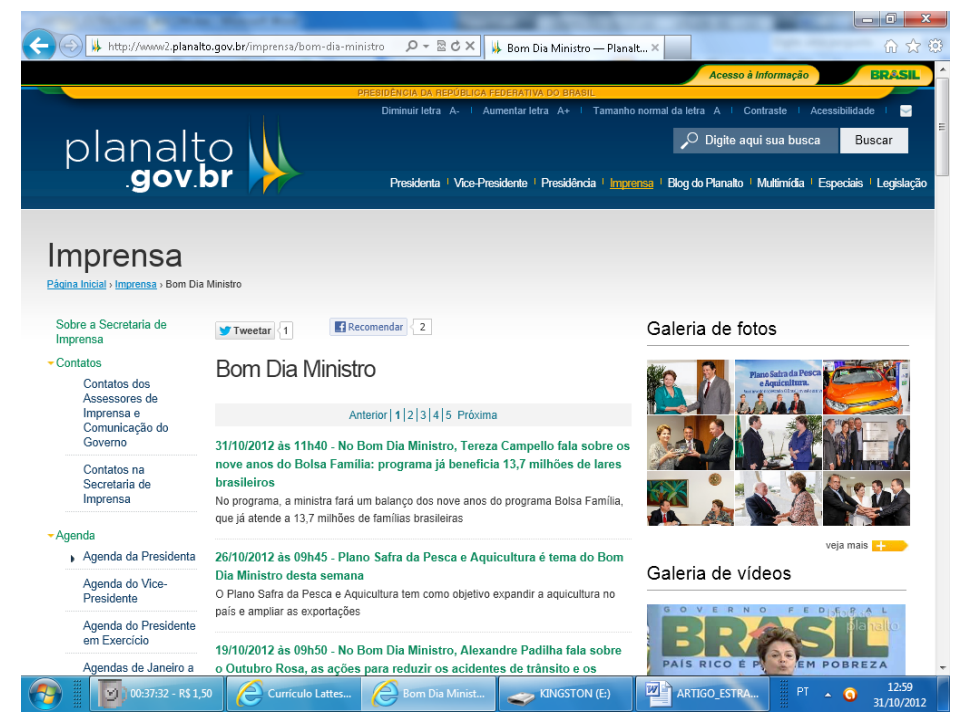

Figure 8 - Link program Good morning Minister Source: website of the Presidency of the Republic (2012)

In Brazil link in Tariff (Figure 9), the links appear monthly program that disseminates information and data on topics such as: A program that allocates $\$ 133$ billion for 
highways and railroads plan to combat crack, and the construction of new units and PSUs basic health, reducing interest rates and portability of account.

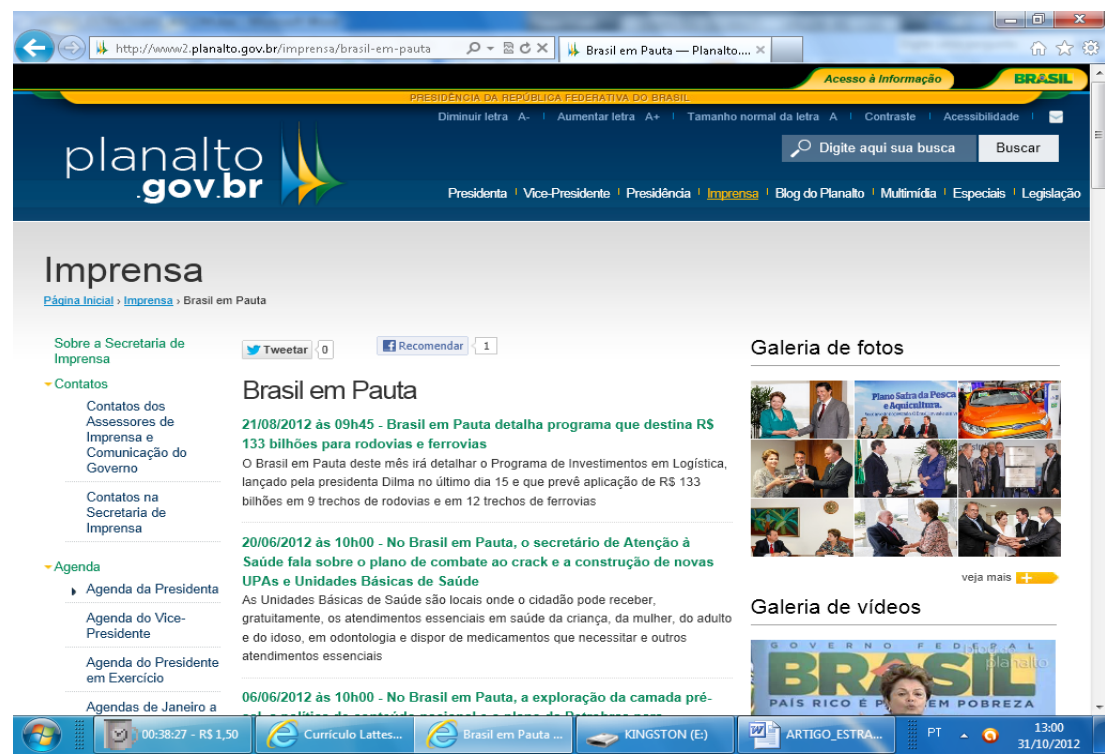

Figure 9 - Link Brazil in Tariff

Source: website of the Presidency of the Republic (2012)

In Brasileiras link (Figure 10) links appear radio programs, which are special editions of Brazil in Tariff program, broadcast live on TV and NBR can be followed via the link on the Press Secretary for the President's website: http : //www2.planalto.gov.br.

The Brazilian program addresses topics such as housing policies, violence against indigenous Brazilian woman, the labor market with a focus to women.

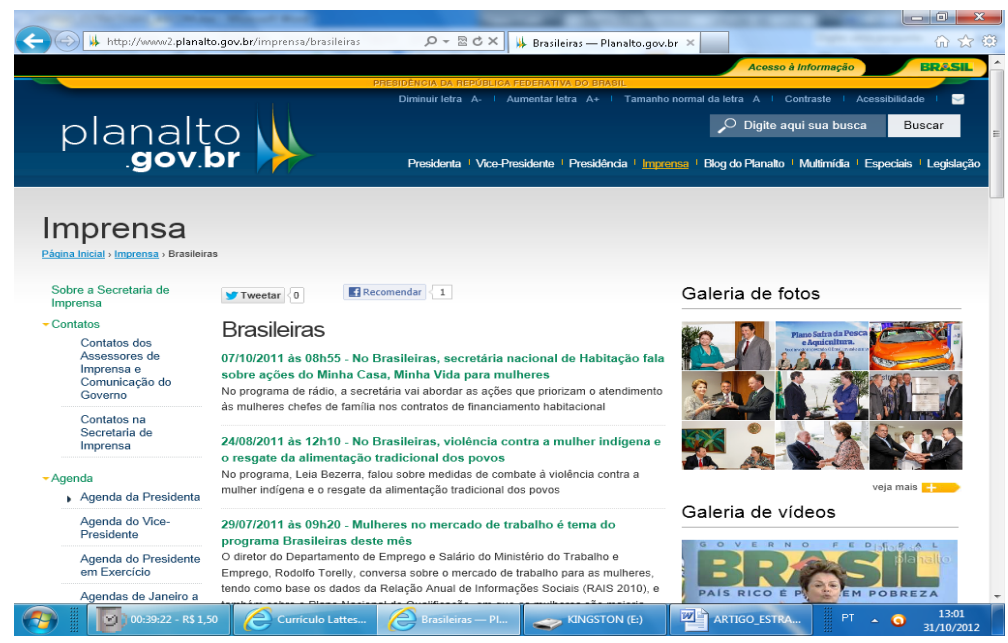

Figure 10 - Link Brazilian

Source: website of the Presidency of the Republic (2012)

Accreditation on the link (Figure 11) contained warnings for press accreditation in the events. 


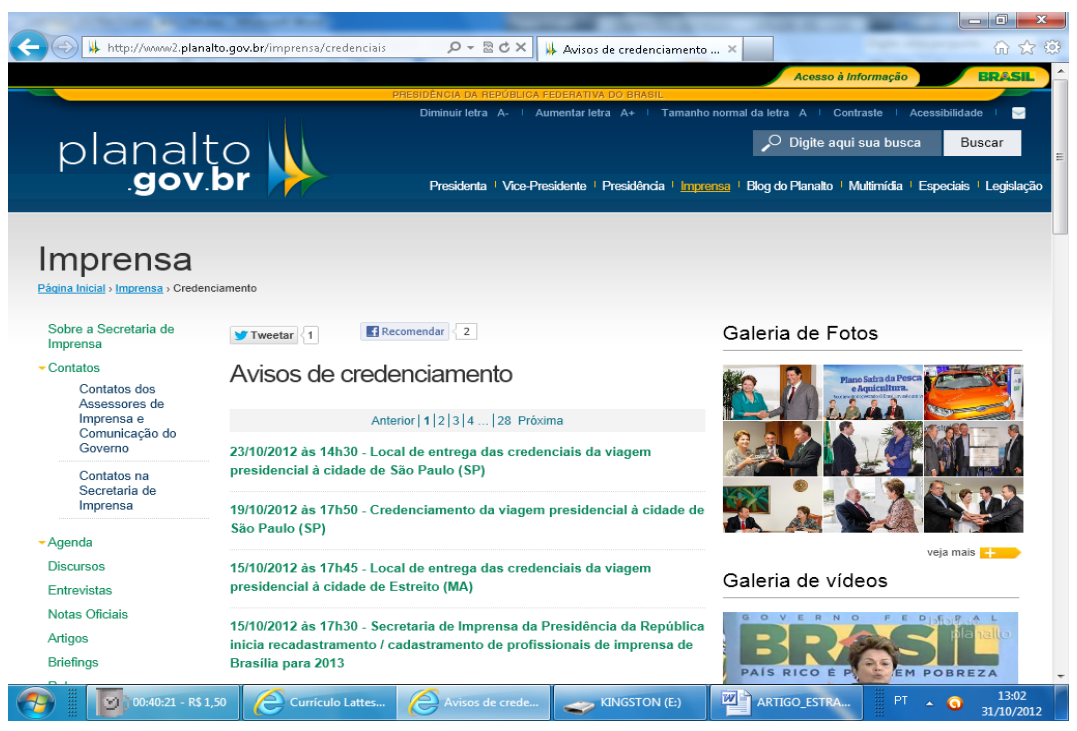

Figure 11 - Link Accreditation

Source: website of the Presidency of the Republic (2012)

Under any of the links President, Vice-President, President, Press, Blog do Planalto, Multimedia, and Special Legislation is available a summary of key information and services portal.

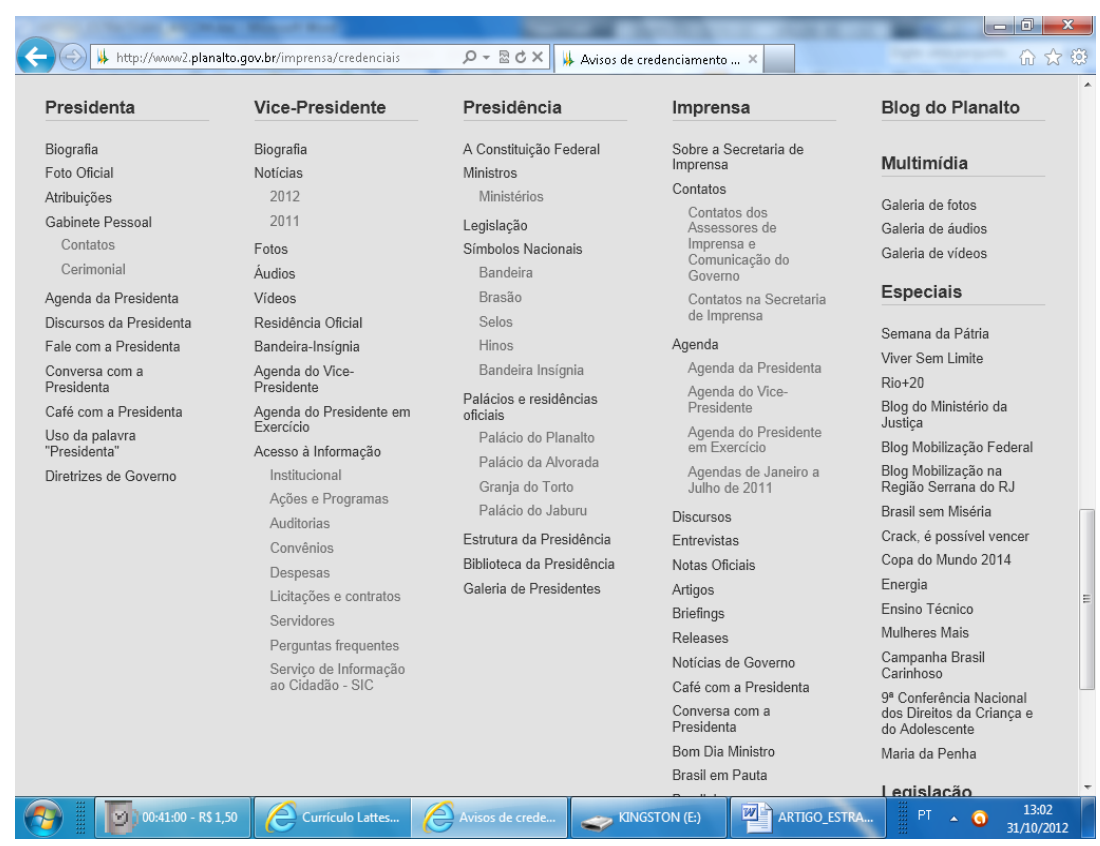

Figure 12 - Links to the main services of the porta Source: website of the Presidency of the Republic (2012)

Beside the Press link on the home page, the Blog do Planalto appears: Highlights, About Blog, Photos, Videos, Audios, Infographics, Special, Issues, Questions \& Answers, Reviews \& tricks and sign up. Are posted on the main page news involving the agenda of President Dilma. 


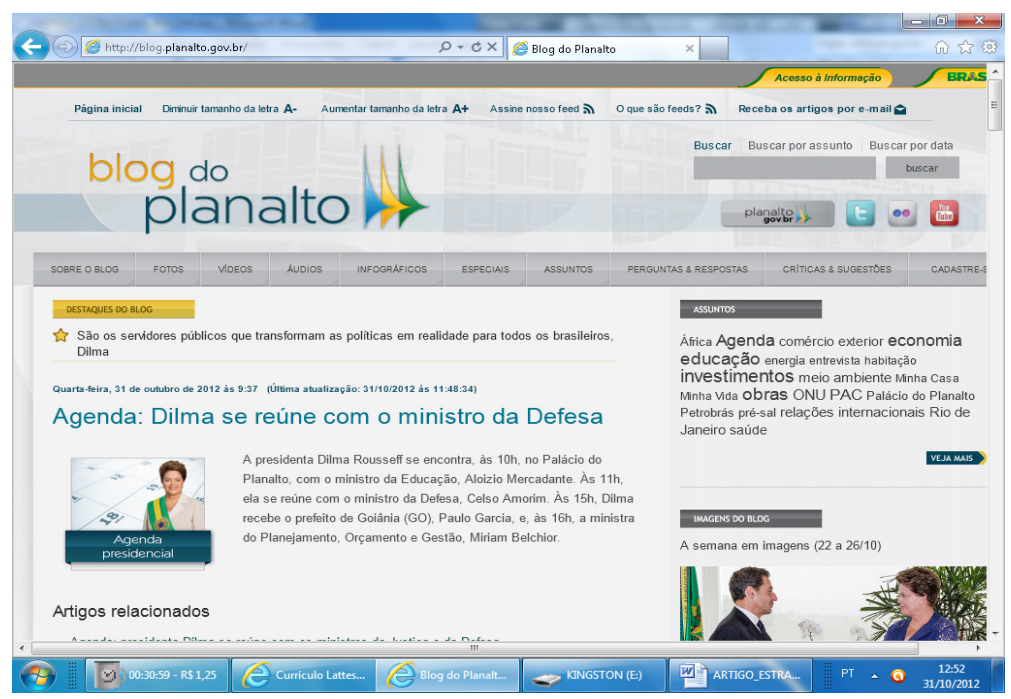

Figure 13 - Link Blog do Planalto Source: website of the Presidency of the Republic (2012)

Also included on the Multimedia page (Figure 14), with Photo Gallery, Gallery Audios and Video Gallery link.

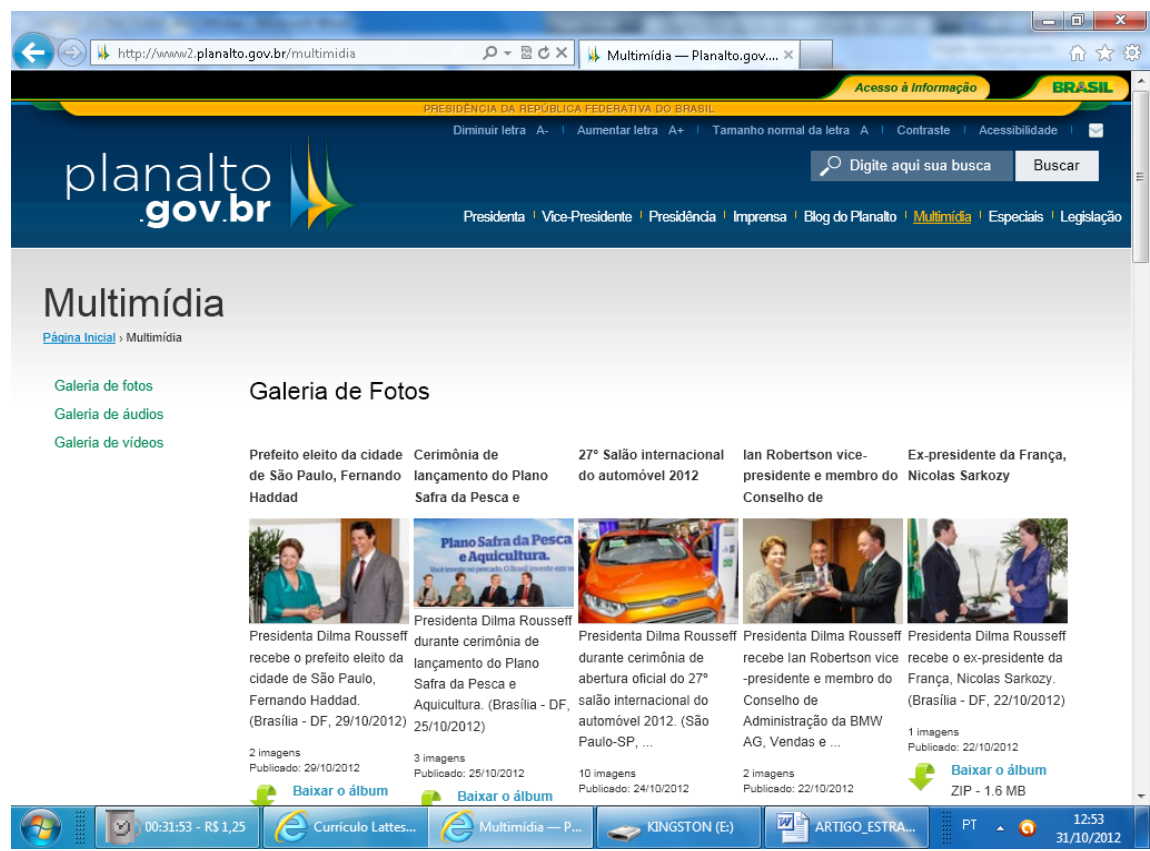

Figure 14 - Link Multimedia

Source: website of the Presidency of the Republic (2012)

Specials on the link (Figure 15) show the specific actions of the federal government on various topics such as: Maria da Penha Law, No Limit Living Week, Nation, Combat Poverty, Children and Adolescents, Brazil without Poverty. 


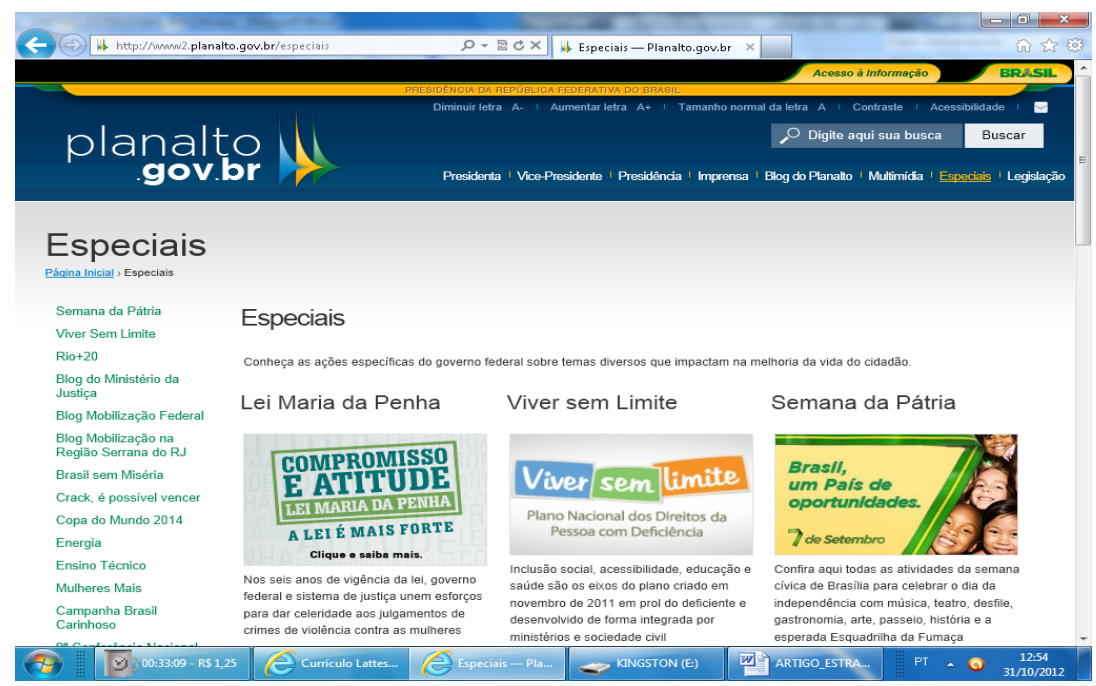

Figure 15 - Special Link

Source: website of the Presidency of the Republic (2012)

Legislation in (Figure 16) link, the presidency provides: link to the Federal Constitution of 1988, as well as links to access codes, common laws, decrees, Daily Review, Provisional Measures. Still in the Legislation link is information on the ministers of the government of Dilma, National Symbols, palaces and official residences, Structure of the Presidency, the Presidency Library and Gallery of Presidents.

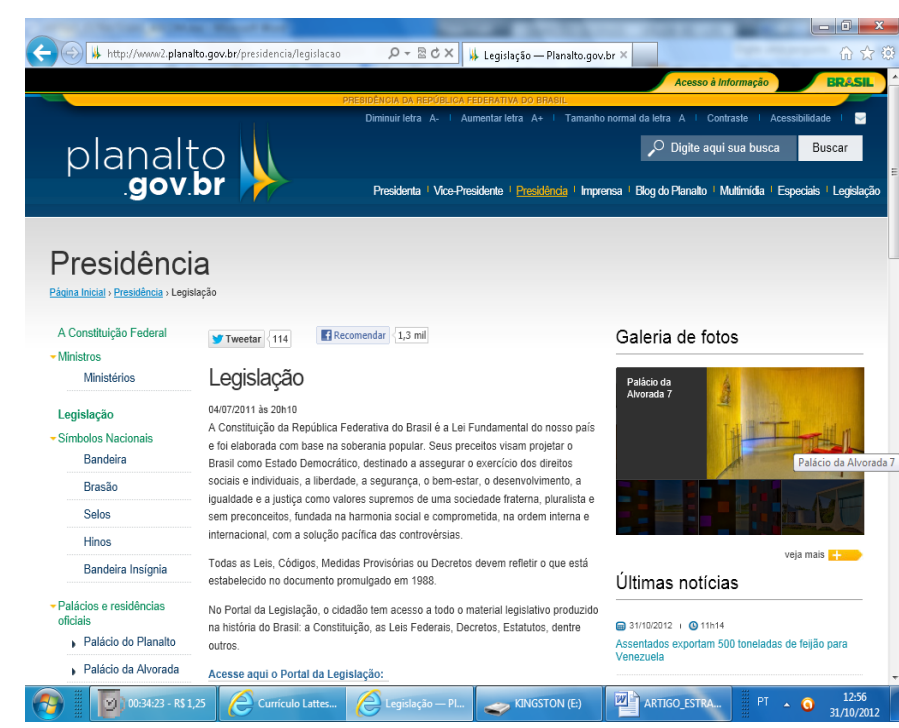

Figure 16 - Link Legislation

Source: website of the Presidency of the Republic (2012)

\section{INTERPRETATION OF THE CORPUS OF RESEARCH}

After quantitative analysis, which described and presented the data page of the Presidency, the research conducts qualitative analysis to the interpretation of data based on the category "space for government communication channels." In the category "space 
for government communication channels," it was found that all the President, Vice-President, President, Press, Blog do Planalto, Multimedia, Special Legislation and the portal of the Presidency links devote space to government communication, here understood as a legitimate form of government accountable and to inform the public actions that are of public interest.

President in link, the links made available on 11, five of them appearing as government communication channels: Tasks, Calendar, Speeches of the President, the President Talk Guidelines and government.

Vice-President at link, 10 links provided on the website, six of them appear as governmental communication channels: news; Official residence; Flag insignia; The VicePresident's agenda; The President's agenda in Exercise and Access to Information.

Already the presidency link, all links provided are part of the government reporting language: the Constitution; ministers; legislation; National symbols; Palaces and official residences; Structure of the Presidency; Library and Gallery of Presidents Presidency.

The Media Link displays inside their 14 to 17 links are shown as governmental communication channels: Agenda; speeches; interviews; Official notes; articles; briefings; Releases; News from Government; Coffee with the President; Good morning Minister; Brazil in Tariff; Brazilian and Reports of the Secretary of the Press.

Blog link on the Plateau are provided information about the agenda of the President and on events which also appears as governmental communication channel.

Multimedia link on the three links Gallery, Gallery of Sound and Video Gallery appear as governmental communication channels.

Also in Special link, all the links appear as governmental communication channels that are specific actions the federal government on various issues of interest to society. Legislation in the link, the links are the same link of the Presidency.

Beyond the interpretation of corpus based on a category of analysis, the research also suggests inferences about the results obtained.

The strategies used in government communications portal of the presidency have the following characteristics: transparency - are easily found in the portal core services of the presidency; interaction - the site on any item citizens can opine, contact and there is also a channel for internet users to speak directly with President Dilma; provision of information - the government channels and communication tools are arranged around the portal, facilitating the navigation of the internet user seeking information of interest to society. The portal also features usability - with only two clicks of the Internet user spends anywhere else and accessibility - in the top menu there are buttons to increase and decrease the sources; There is also possibility to change the color tone, emphasizing content over the bottom of the screen, making navigation easier.

The news and reports available on the schedule page of facts relevant to the public, as stated in the titles of News Government link in the press area: "Government has released $£ 3.2$ billion to mitigate the effects of drought"; "Free Application Citizen calculator lets you know how many installments and interest payable to repay debts"; "SUS gives ample support to those who want to stop smoking"; "Collection with 360 books will be shipped to the 85200 public schools education libraries". 


\section{Final Thoughts}

Study the strategies of government of President Dilma Rousseff communication focusing on the presidential website allows us to make some observations. The proposed hypotheses were verified, the question that guided this research was identified and the study objectives were achieved.

The question that guided this research - and the presidency in the administration of President Dilma communicates with society through the portal of the Presidency? Can be answered in the following terms: the Presidency of the Republic, in his website, communicates in a transparent and accessible way with the company, providing strategic government communication channels and tools page.

The general hypothesis that the unity of this study was confirmed: the strategies of government communication in the administration of President Dilma appear as satisfactory because the used channels and tools are used correctly and enable proximity of government to society, paying bills of its activities and services and publishing activities of interest to the people. In this sense, the government of President Dilma communication appears as a suitable example of public communication.

The content analysis identified the government communication channels and tools used by Office of Communications and the portal was also possible to show how the presidency provides information of public interest in your page.

The research found that the strategies used in government communications portal of the presidency have the following characteristics: transparency, interaction, contentdisposition that facilitates navigation and usability.

The study also noted that although there is a predominance of political marketing in the past administrations, the administration of President Dilma through the portal, gave greater emphasis to government communication.

The portal of the presidency through their channels and government communication tools presents issues that purports to be part of the individuals agenda. Such content may contribute to the conduction and the formation of representations of the world of people who build them indirectly. Thus, the federal government has a valuable tool for presenting information and issues and foster discussion.

\section{REFERENCES}

Bardin, L. (1977) Análise de Conteúdo, Lisboa: Edições 70.

Brandão, P. E. (2009) Conceito de comunicação pública, in Duarte, J. (Org.). Comunicação Pública: Estado, mercado, sociedade e interesse público, 2 ed, São Paulo: Atlas, pp. 1-33.

Datafolha. Disponível em <http://datafolha.folha.uol.com.br/po/ver_po.php?session=1024>. Acesso em $12 / 09 / 2012$.

Herscovitz, G. H. (2007) Análise de conteúdo em jornalismo, in Lago, C. \& Benetti, M. (Orgs.). Metodologia de Pesquisa em Jornalismo, Petrópolis: Vozes.

Júnior, W. C. da F. (2011) Análise de conteúdo, in Duarte, J. \& Barros, A. (orgs). Métodos e técnicas de pesquisa em comunicação, 2 ed, São Paulo: Atlas, pp. 280-303. 
Lippmann, W. (2008) Opinião pública, Tradução e prefácio de Jacques A. Wainberg, Petrópolis: Vozes.

Matos, H. (1999) Das relações públicas ao marketing público: (dês)caminhos da comunicação governamental, in Corrêa, T. G, F \& Gomes, S. (Orgs.) Comunicação, marketing, cultura: sentidos da administração do trabalho e do consumo, São Paulo: ECA/USP; CLC, pp. 58-66.

Presidência da República Federativa do Brasil. Available at <http://www2.planalto.gov.br/>, acess in 12/09/2012.

Rego, F. G. T. do (1986) Comunicação empresarial/comunicação institucional: conceitos, estratégias, sistemas, estrutura, planejamento e técnicas, São Paulo: Summus.

Rego, F. G. T. do (1987) Jornalismo empresarial: teoria e prática, 4 ed, São Paulo: Summus.

Rego, F. G. T. do (1985) Marketing político e governamental: um roteiro para campanhas políticas e estratégias de comunicação, São Paulo: Summus.

Traquina, N. (2004) Teorias do Jornalismo: porque as notícias são como são, 2. ed, Florianópolis: Insular. $* * *$

Received: 03-06-2014

Accepted: 06-10-2014 